\title{
Device Handling Code
}

National Cancer Institute

\section{Source}

National Cancer Institute. Device Handling Code. NCI Thesaurus. Code C95359.

A coded value specifying handling requirements for a device. 